\title{
Integrated application of the analytic hierarchy process and the geographic information system for flood risk assessment and flood plain management in Taiwan
}

\author{
Yi-Ru Chen · Chao- Hsien Yeh $\cdot$ Bofu Yu \\ ABSTRACT Flooding is one of the major natural hazards in Taiwan and most of \\ the low-lying areas in Taiwan are flood prone areas. In order to minimize loss of \\ life and economic losses, a detailed and comprehensive decision making tool is \\ necessary for both flood control planning and emergency service operations. The \\ objectives of this research were (i) to develop a hierarchical structure through the \\ Analytic Hierarchy Process (AHP) to provide preferred options for flood risk \\ analysis, (ii) to map the relative flood risk using the Geographic Information System \\ (GIS), and (iii) to integrate these two methodologies and apply them to one urban \\ and one semi-rural area in central Taiwan. Fushin Township and the floodplain of \\ Fazih River (1 km on either side of the channel) in Taichung City were selected for \\ this study. In this paper, the flood risk is defined as the relative flood risk due to \\ broken dikes or the failure of stormwater drainage systems. Seven factors were \\ considered in relation to the failure of stormwater drainage, and five to that of \\ broken dikes. Following well-defined procedures, flood maps were drawn based on \\ the data collected from expert responses to a questionnaire, the field survey, satellite \\ images, and documents from flood management agencies. The relative values of \\ flood risk are presented using a $200 \mathrm{~m}$ grid for the two study areas. It is concluded \\ that integration of AHP and GIS in flood risk assessment can provide useful detailed \\ information for flood risk management, and the method can be easily applied to \\ most areas in Taiwan where required data sets are readily available.
}

\section{Keywords Flood risk - Decision making - Analytic Hierarchy Process (AHP) · Geographic Information System (GIS)}

\section{Introduction}

In Taiwan, flooding is one of the major natural hazards causing death and millions of dollars of economic losses every year. Typhoons in summer and fall bring heavy and intense rainfall to Taiwan and cause great damage. The costs of flood damage recovery are usually much greater than the costs of flood prevention in Taiwan. Good flood management is thus important to reduce the flood risk.

A comprehensive flood risk assessment usually contains a range of analyses, such as risk, technical, cost, problem, policy, loss analysis and prevention performance analyses. The information from the assessment can be used for flood risk management. A number of approaches have been used to provide information

Y. R. Chen $(\backslash) \cdot$ B. Yu

School of Engineering, Griffith University

170 Kessels Road, Nathan, Brisbane, Queensland 4111, Australia

e-mail: lily.chen@griffith.edu.au

C. H. Yeh

Department of Water Resources Engineering and Conservation, Feng Chia University No. 100 Wenhwa Road, Seatwen, Taichung 40724, Taiwan 
for flood risk management. Most studies applied hydrologic and hydraulic models to simulate flood runoff and runoff in low-lying and flood-prone areas (Anselmo et al. 1996; Booij 2005; Smith 1994). Brimicombe and Bartlett (1996) assessed the flood risks using hydraulic models coupled with the Geographic Information System (GIS) and the Digital Elevation Model (DEM) to map the area and depth of inundation. This type of flood risk assessment provides information on the probability of flood occurrence, magnitude of the event, location and depth of the inundation for flood management.

Flood risk can also be assessed with multi-criteria analysis of the depth of inundation generated by hydraulic and hydrologic models. An example of this approach is to combine the use of hydrologic or hydraulic models with the Multi Attribute Utility Theory (MAUT) (Meyer et al. 2009) or Analytic Hierarchy Process (AHP) to estimate flood damage (Wang et al. 2002; Zhang et al. 2002). The multicriteria analysis methods provide 'a framework which can handle different views on the identification of the elements of a complex decision problem, organize the elements into a hierarchical structure, and study the relationships among components of the problem' (Boroushaki and Malczewski 2010, p302).

Decision makers could study and understand the problems through the multicriteria analysis methods such as AHP which solves complex problems by structuring the factors into a hierarchical framework (Saaty 1980). AHP has been widely used for solving various problems (Golden et al. 1989). For example, it was used by Willett and Sharda (1991) to select the optimal flood control projects for the Grand River and Tar Creek in Miami, USA.

Another flood risk analysis using AHP and mapped by GIS has been applied to the Kosi River Basin, India (Sinha et al. 2008). The flood risk in the case study was defined as susceptibility of inundation, along with loss of life and property. In addition, the decision factors for flood risk of the AHP matrix include elevation, land cover, distance to active channels and population density. The flood risk analysis from Sinha et al. (2008) assumed that flood damage caused by inundation in areas of high population density could be considered as loss of life and property.

Cheng and Wang (2004) employed a two-dimensional diffusive overland flow model to simulate inundation status in northern Taiwan, and used GIS to illustrate the area and depth of inundation. Based on the inundation map, they developed a model to evaluate the possible damage from floods by using grey AHP.

AHP was used to rank the importance of loss of life and different properties, which is the flood index (Sinha et al. 2008; Cheng and Wang 2004). The total ranks of the index of possible damage were then mapped by using GIS. The flood maps can be very useful for flood control planners to make cost-effective decisions, where money needs to be spent.

The National Science and Technology Program for Hazards Mitigation published an inundation potential map for Taiwan. The inundation potential was assessed by a numerical model which was integrated with rainfall data, topography, and land use for surface roughness coefficient. The inundation potential map can be used as a reference for the government, urban planners or property investors (Chen et al. 2000).

These aforementioned relative flood risk analyses, determined by numerical models, provide flood water depth and flow for different events that cannot be presented by an AHP model. However, AHP can collect the possible problems such as factors which cause and prevent floods, and reduce flood damage, and evaluate the preferred options for flood risk management.

Being one of the major disasters in Taiwan, flooding is often caused by extended 
periods of precipitation in drainage systems resulting in the failure to cope with excessive runoff. Sometimes, the inundation occurs because of the broken dikes caused by high water levels during flood events.

The objectives of this study were to create a meaningful flood risk index which is related to likelihood of inundation by using AHP and using GIS to show the spatial distribution. The relative flood risk was evaluated using AHP and mapped with GIS at $200 \mathrm{~m}$ resolution. This new approach was tested for two areas in central Taiwan, one urban and one semi-rural.

\section{Study area and methodology}

\subsection{Study area}

Located around the Tropic of Cancer, Taiwan is an island with the main mountain ranges running north to south along the east coast. The highest point on the island reaches an elevation of 3,997 meters above sea level. Taiwan is mountainous, rugged, and there are numerous small to medium-sized coastal catchments with relatively short waterways and steep slopes. The rainy season is from May to October. The mean annual rainfall is approximately 2,500mm which is distributed unevenly with a positive correlation between rainfall and elevation.

Typhoons usually hit the island between June and September every year. From 1958 to 2009 , the average number of typhoons that hit Taiwan is approximately 4.9 per year (Central Weather Bureau 2009). Recent examples include Typhoon Mindulle in 2004 which killed 33 people and caused losses of over NT\$ 8.9 billion (equivalent to US\$280 million). The loss from Typhoon Aera in 2005 was NT\$7.7 billion (equivalent to US\$240million).

The total area of Taiwan is $35,800 \mathrm{~km}^{2}$ with a population of 23 million which results in an average population density of approximately 640 persons per $\mathrm{km}^{2}$. However, seventy percent of the population lives in large cities in western Taiwan, with a population density of around 2,600 persons per $\mathrm{km}^{2}$.

Due to the high population density and the demand for land in Taiwan, development of urban and industrial areas often takes place on flood plains or floodprone areas, and levees are very common for flood protection. Mobile pumps are usually used to redirect flood water during and after floods to reduce flood damage. Floods are a common natural hazard and mostly impact on the populated western parts of Taiwan such as Taichung City and Fushin Township (Fig. 1).

The Fazih River in Taichung and Fushin Township were selected as the study areas. Taichung City is a well developed urban area with a high density of residential and commercial land use. Floods in Taichung are usually caused by river water overflowing broken levees along the Fazih River or the failure of stormwater drainage systems downstream to the Fazih River. According to the flood damage report from Taichung City Council (2006), during the typhoon periods in 2004 and 2005, the inundated areas were located in the northwest Xitun District, southern Xitun Road, northern Anho Road, and along the Fazih River in Nantun District. The study area of Taichung and the historically inundated locations are shown in Fig. 2. 


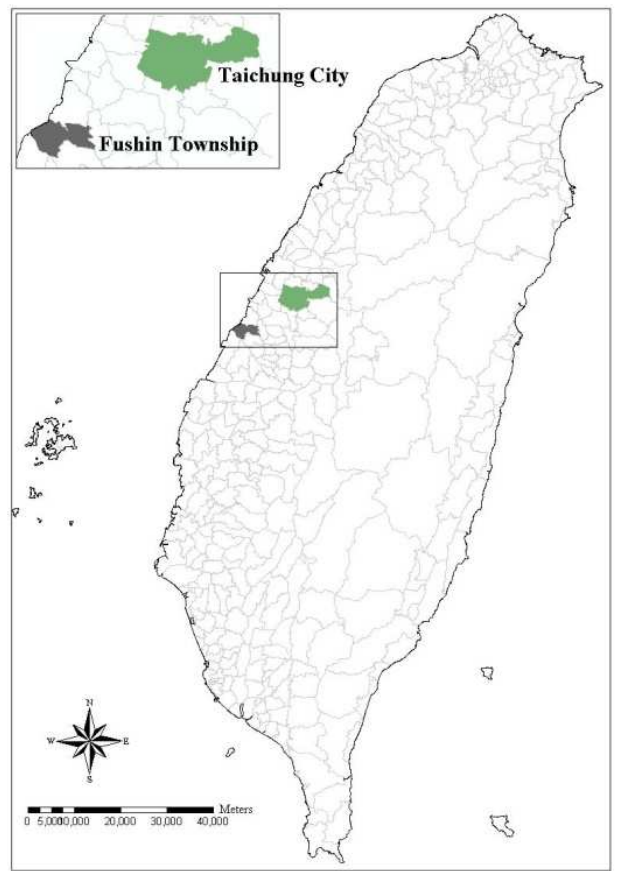

Fig. 1 Study areas in Taiwan

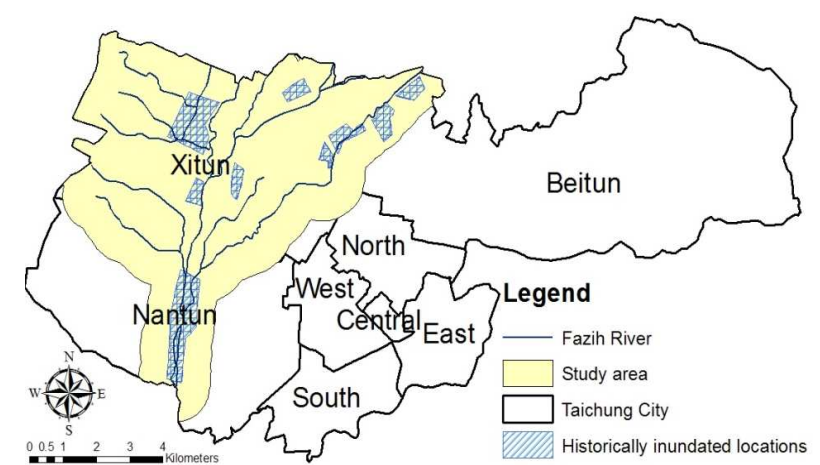

Fig. 2 Study area of Fazih River with 1 kilometer buffer on both sides of the main channel in Taichung City

Fushin Township is a semi-rural area located on the coast where the land use is mainly for agriculture, with limited industrial and commercial activities. Floods in Fushin Township usually occur during storm events when coupled with high tides that generally cause the river to overflow levees and overload the stormwater drainage systems. Based on the report of the Regulation Project of Flood-prone Areas (Water Resources Agency 2006), the inundated areas during the typhoon periods in 2004 and 2005 were located near Yongle elementary school, Yuanlin canal at Quanyu village section and Hoshizai village (Fig. 3). 


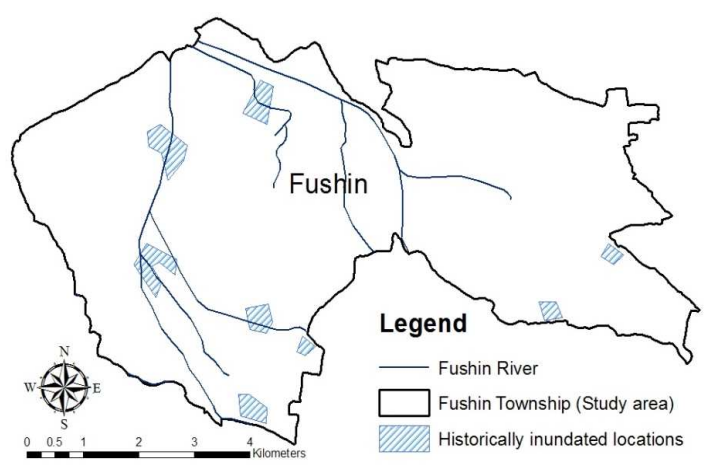

Fig. 3 Study areas of Fushin Township

\subsection{Methodology}

To define the flood risk for an area, this study first categorized various factors in relation to flood events based on literature reviews and historical records in Taiwan (Fig. 4). The questionnaire covers the factors that cause flooding all over Taiwan as it is a standardised tool that can also be used for other areas, large or small in Taiwan. The questionnaires were given to experts and their answers regarding relative flood risk factors were then weighted and processed by the AHP software known as Super Decision.

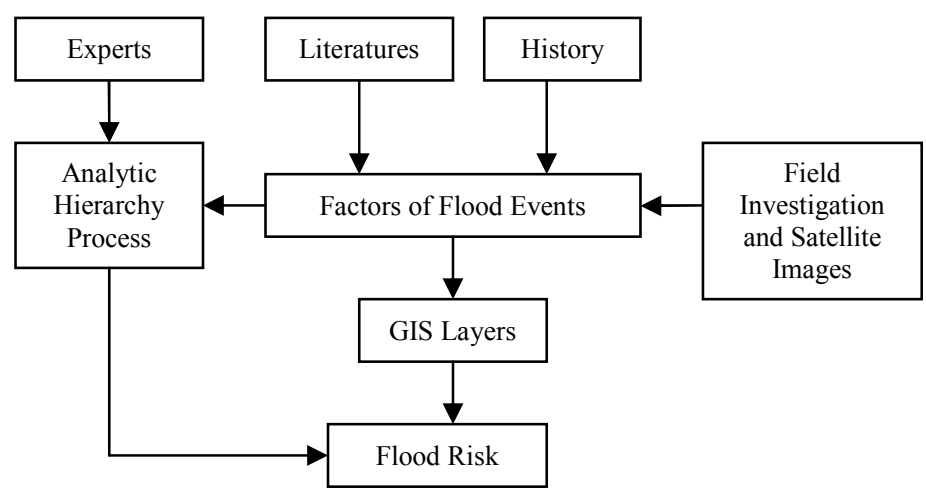

Fig. 4 Research methodology

The two study areas were divided into cells at $200 \mathrm{~m}$ resolution. The one $\mathrm{km}$ buffers along the main channels in the Fazih River and Fushin River basins were also divided into $200 \times 200 \mathrm{~m}^{2}$ cells for evaluating the potential of inundation due to the failure of broken dikes. The GIS was then used to produce the layers of these factors in the $200 \times 200 \mathrm{~m}^{2}$ cells, along with the spatial conditions of the study areas through field investigation and satellite images. The comprehensive results of flood risk of the study areas as well as hot spots with high relative flood risk were identified by aggregating layers of weighted factors. The detailed operation procedures are described in the following sections. 


\subsubsection{Analytic Hierarchy Process (AHP)}

A risk measure contains the probability and the consequences of an event (Jonkman et al. 2003). Fig. 5 illustrates the probabilities and consequences of natural disasters with manmade protections. The risk factors, risk exposures, regional geographical characteristics and existing mitigation measures collectively determine the probability occurrence of natural disasters. The consequences of natural disasters are the related to a combination of probabilities and existing mitigation measures. Due to the recurring nature and adverse impacts of floods, many urban authorities have flood control plans and infrastructure to reduce the flood risk. For example, increasing the height of dams or levees could reduce the flood risk and installing mobile pumps could reduce the flood damage. By establishing appropriate facilities and changing levee heights after floods, the flood risk is then lower than the former risk.

In many flood prone areas, the Taiwanese government allocates resources to develop flood control plans and construct flood mitigation measures such as levees and flood walls to reduce the flood risk. Because the probabilities and consequences of flooding refer to complex and interrelated factors, the AHP is utilized to deal with this complicated problem. AHP is a framework based on mathematics and psychology (Saaty 1980). AHP involves the following steps: (1) structuring possible factors for the problem into a hierarchy; (2) arranging the factors for each alternative; (3) developing the criteria for alternatives; (4) evaluating the importance of alternatives; and (5) analyzing the weight of each factor.

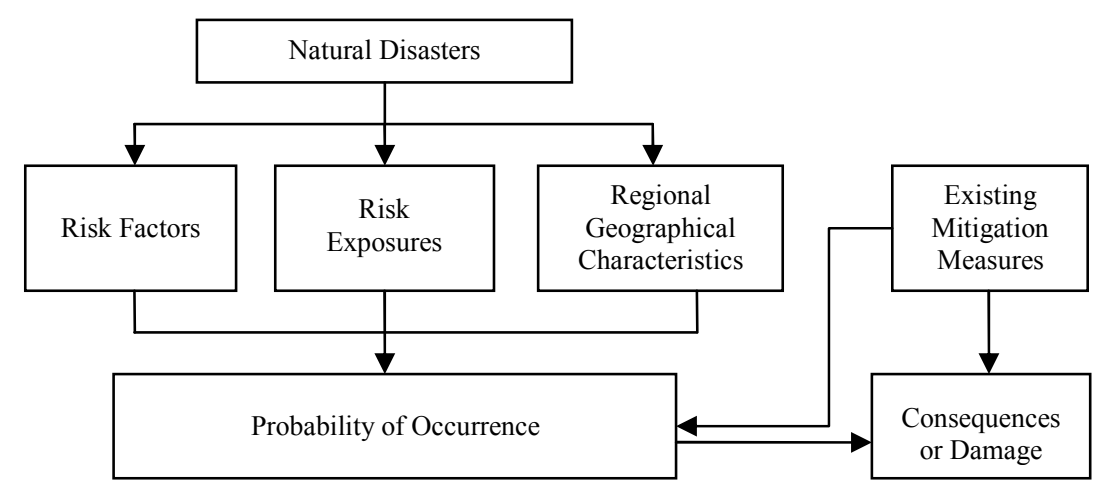

Fig. 5 Conceptual structure of probability and consequences of natural disasters

An AHP questionnaire was designed with a focus on the relevant flooding problems for this study. The factors and the criteria are relevant to all regions in Taiwan to allow the questionnaire to be used for comparative study of flood risk in Taiwan. Two sections in the AHP questionnaire were designed to identify the relative flood risk due to the failure of stormwater drainage systems and broken dikes. The first section includes flood protection factors and factors causing failure of drainage systems. The second section includes factors that cause dikes to break causing the water to overflow resulting in overloaded stormwater drainage systems.

The importance of each decision factor is scaled from 1 (equally important) to 9 (extremely more important) (Saaty 1980) (Table 1). An example of the comparative matrix is shown in Table 2. From the responses shown in Table 2, it can be seen that factor A is more important than factor B according to the experts surveyed. The AHP 
questionnaire was sent to experts for validation and was developed from this feedback process. The criteria of the factors in the AHP questionnaire are described in the next section.

Table 1 Definition of comparative importance

\begin{tabular}{|c|c|c|c|c|c|c|c|c|c|c|c|c|c|c|c|c|}
\hline \multicolumn{6}{|c|}{ Comparative importance } & \multicolumn{8}{|c|}{ Definition } & & & \\
\hline \multicolumn{6}{|c|}{1} & & \multicolumn{7}{|c|}{ Equally important } & & & \\
\hline \multicolumn{6}{|c|}{3} & \multicolumn{8}{|c|}{ More important } & & & \\
\hline \multicolumn{6}{|c|}{5} & & \multicolumn{7}{|c|}{ Strongly more important } & & & \\
\hline \multicolumn{6}{|c|}{7} & \multicolumn{8}{|c|}{ Very strongly more important } & & & \\
\hline \multirow{2}{*}{\multicolumn{3}{|c|}{$\begin{array}{l}9 \\
2,4,6,8\end{array}$}} & & & & & \multirow{2}{*}{\multicolumn{7}{|c|}{$\begin{array}{l}\text { Extremely more important } \\
\text { Intermediate vales }\end{array}$}} & & & \\
\hline & & & & & & & & & & & & & & & & \\
\hline \multicolumn{17}{|c|}{ Table 2 Comparative matrix } \\
\hline \multicolumn{16}{|c|}{ Comparative importance } & \\
\hline 7 & 6 & 5 & 4 & 3 & 2 & 1 & 2 & 3 & 4 & 5 & & & 7 & 8 & 9 & Factor \\
\hline & & & & $\sqrt{ }$ & & & & & & & & & & & & B \\
\hline
\end{tabular}

\subsubsection{The factors of flooding}

The first section of the questionnaire is based on the relevant literature mentioned previously. The factors contributing to flooding due to the failure of drainage systems are rainfall, topography, the capacity of stormwater drainage systems, the existence of water gates or pumping stations, mobile pumps, and management practices. The second section deals with flooding caused by broken dikes. The factors linked to flooding caused by broken dikes are the material and conditions of the levees, the angle between the bank and main flow direction, the bank slope, the river channel slope, rainfall, topography, whether the river is tidal affected, drainage systems, the existence of water gates or pumping stations, mobile pumps, and management practice.

\section{(1) Rainfall}

Precipitation data from 170 rainfall observation stations in Taiwan were collected from the Inquiry and Supply System of Water Resources Data website (Water Resources Agency, Ministry of Economic Affairs; http://gweb.wra.gov.tw/wrweb). In 2004, 29 typhoons occurred in the Southeast Asian region and nine of them hit Taiwan. Floods in three out of the nine typhoons (Mindulle, Nock-Ten and Nanmadol Typhoon) caused considerable damage and losses to Taiwan. The 2004 annual precipitation was similar to the average annual precipitation for the decade 1997-2006. The rainfall data of 2004 were analyzed using the Ordinary Kriging Method with spherical semivariogram model in the GIS software. The spatial distribution of annual precipitation is shown in Fig. 6. In addition, the 2004 annual precipitation was summarized in terms of cumulative spatial distribution in percent (Fig. 7). The percentages of total precipitation were divided into four levels as follows: under $25 \%(\leq 1842 \mathrm{~mm})$, between $25 \%$ to $50 \%$ (1842mm $-2394 \mathrm{~mm}), 50 \%$ to $75 \%$ (2394mm - 3154mm) and over $75 \%(\geq 3154 \mathrm{~mm})$. 


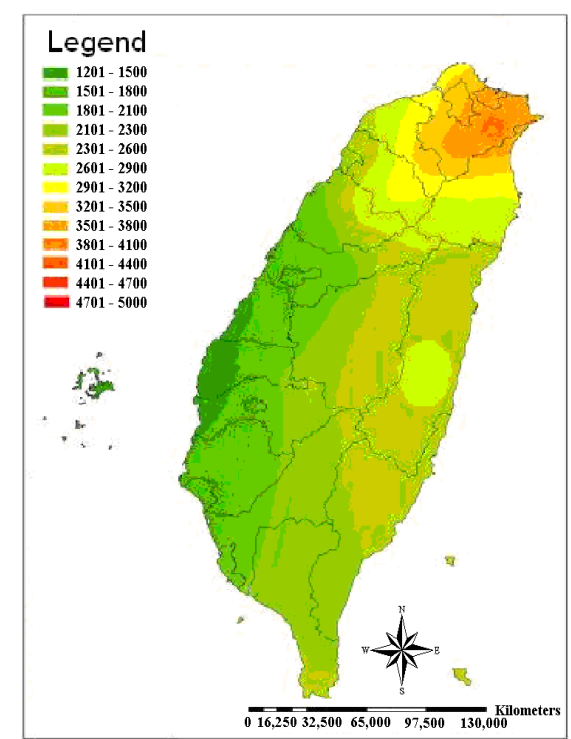

Fig. 6 Annual precipitations in 2004

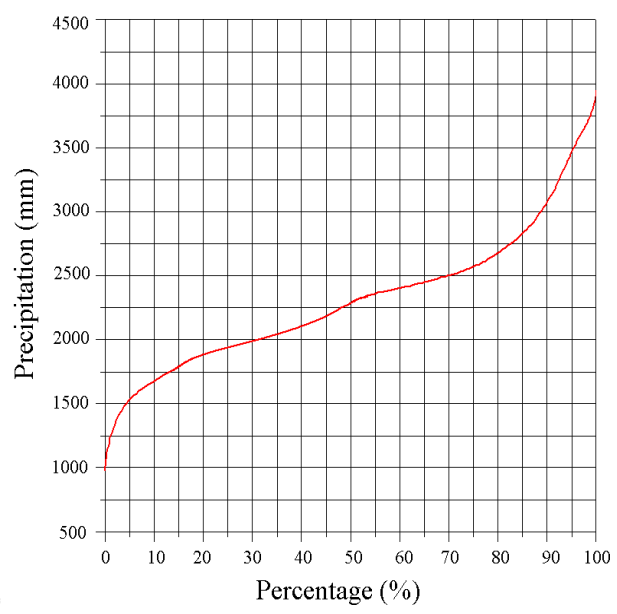

Fig. 7 Percentage of area with annual precipitation less than the given value in 2004

\section{(2) Topography}

The WinGrid system developed by Lin et al. (2001) was originally designed for calculating the slope length factor of watershed soil loss and for estimating the sediment yield. In the current study, WinGrid was used to analyze the topography with a $40 \mathrm{~m}$ grid resolution of the Digital Terrain Model (DTM). Generally, the depressed areas have a higher risk of flooding and so the direction of water flow is applied to indicate and define the topographic condition of each cell. If the directions of water flow at the boundary of one $200 \mathrm{~m} \times 200 \mathrm{~m}$ cell all flow-in, it means that this $200 \mathrm{~m} \times 200 \mathrm{~m}$ unit is a depressed area. On the other hand, a cell is defined as a crest area if the directions of water flow at its boundary all flow-out. Accordingly an area in between depressed and crest areas would have water flow through it. Therefore, the topography factor has been divided into three classes: inflow, out-flow and through-flow.

\section{(3) Tidal affected river}

During heavy rainfall, pump stations might fail due to the effect of tides. The area near the tidal affected river reach is always considered as an area with high potential for flooding.

\section{(4) Slope of river channel}

The slope of a river channel is classified into three different levels consisting of slight, moderate, and steep slopes. In this study, a slight slope was defined as being less than $1 \%$, a moderate slope as being between $1 \%$ and $5 \%$ and a steep slope as more than $5 \%$. The slope of a river channel was analyzed by GIS software with a $40 \mathrm{~m}$ grid resolution of the DTM.

(4) Stormwater drainage systems 
A stormwater drainage system is an important element of flood control measures (Grigg et al. 1975). Stormwater drainage systems are designed to withstand a single flood of a certain magnitude and average recurrence interval. In Taiwan, the drainage systems were designed for floods having flood recurrence intervals (FRI) of 1 in 5,1 in 10 , or 1 in 20 years. These three flood recurrence intervals were considered in this study.

(5) Water gate, pumping station and maintenance

The location of water gates and pumping stations can be found on the Hazard Mitigation Center of Water Resources Agency website (Ministry of Economic Affairs; http://gweb.wra.gov.tw/proj109/hyhome.htm). For this current study, the management status of these gates and stations was evaluated by their maintenance conditions.

(6) Mobile pumps

During heavy rainfall, mobile pumps can be deployed to a depressed or flooded area to pump water for flood control purposes. The number and location of mobile pumps were provided by the related government agency.

(7) Material, conditions and positions of levee

The different construction materials of levees provide different strengths. In Taiwan, there are six types of levee and bank revetment, i.e. earth levee, riprap levee, riprap bank revetment, wire cylinder bank revetment, riverbank revetment, and reinforced concrete (RC) revetment. The conditions of levees are defined according to whether or not they have cracks. Broken dikes in heavy rainfall events are often associated with levees with cracks. The positions of levees are defined as angles of the main flow of a river approaching the levee. Main river flow approaching a levee at an acute angle is always one of the main causes of cracks in the levee. In this study, the approaching angles of river flow were presented as an angle, with $180^{\circ}$ or parallel, acute angle $\left(\leq 90^{\circ}\right)$, and obtuse angle $\left(\geq 90^{\circ}\right)$. Fig. 8 illustrates the angles of river water approaching a levee; for example, the approaching angle of $180^{\circ}$ appears in a straight stream, acute and obtuse angles occur in a curved stream.

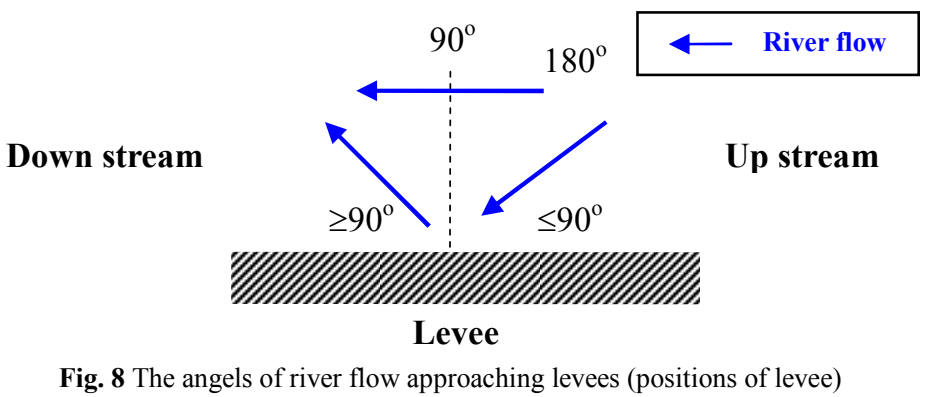

\subsubsection{Expert survey}


The validity of the AHP questionnaire for this study was then confirmed by three returned results from six experts in flooding analysis and water resources. 55 questionnaires were then sent to hydraulic, water resources and flood experts from the Taiwanese government, academia, and chartered professional engineers. Of the 33 returned questionnaires, a $66 \%$ response rate, 14 were from university professors and researchers, six from government agencies, and 13 chartered professional engineers with expertise in hydrology and flood control. These experts are located in different regions, such as north-western, middle-western, south-western and eastern Taiwan. The advantage of distributing the questionnaire to three different areas and different regions is to reduce the bias in evaluating the alternative flooding factors.

\subsubsection{Datasets}

The data for evaluating flood risk were derived from different sources in digital and print form. Images taken by the Chinese Satellite No. 1 on 29 March, 2006 for Taichung City and 23 August, 2006 for Fushin Township were used to locate flood protection works such as water gates and levees in the study areas. Additional information from the Water Resources Agency of Taiwan about Taichung City and Fushin Township was also used for analyzing flood factors.

\section{Results}

The relative flood risk for each $200 \times 200 \mathrm{~m}^{2}$ unit is calculated with the weight of factors. There are a number of different ways to analyze the weight of factors, such as calculating by mathematical formulas or using AHP software. In the study, Super Decision software was used to analyze the numerical values of inundation factors. The weights of flooding were analyzed according to the Fuzzy theory (Zadeh 1968). Results are shown as numerical values, which are the weights of relative flood risk. The analytical results of the AHP questionnaire from Super Decision are shown in Table 3 and Table 4.

Table 3 Factor weights of inundation potential due to the failure of drainage systems

\begin{tabular}{|c|c|c|c|c|c|}
\hline Factors & Levels & Govern. & Acad. & Industry & Overall \\
\hline \multirow{4}{*}{ Precipitation } & Under $25 \%$ & 0.057 & 0.085 & 0.157 & 0.105 \\
\hline & Between $25 \%$ to $50 \%$ & 0.159 & 0.180 & 0.259 & 0.204 \\
\hline & Between $50 \%$ to $75 \%$ & 0.305 & 0.268 & 0.412 & 0.324 \\
\hline & Over $75 \%$ & 0.518 & 0.360 & 0.508 & 0.441 \\
\hline \multirow{3}{*}{ Topography } & Out flow & 0.016 & 0.039 & 0.038 & 0.035 \\
\hline & Through flow & 0.076 & 0.088 & 0.099 & 0.049 \\
\hline & In flow & 0.128 & 0.146 & 0.210 & 0.171 \\
\hline \multirow{2}{*}{$\begin{array}{l}\text { Tidal affected } \\
\text { river }\end{array}$} & In a tidal affected river section & 0.023 & 0.037 & 0.039 & 0.036 \\
\hline & Not in a tidal affected river section & 0.071 & 0.112 & 0.067 & 0.090 \\
\hline \multirow{3}{*}{$\begin{array}{l}\text { Stormwater } \\
\text { drainage } \\
\text { systems }\end{array}$} & 20 years of FRI flow & 0.032 & 0.046 & 0.054 & 0.048 \\
\hline & 10 years of FRI flow & 0.060 & 0.103 & 0.080 & 0.088 \\
\hline & 5 years of FRI flow & 0.105 & 0.152 & 0.116 & 0.133 \\
\hline \multirow{2}{*}{$\begin{array}{l}\text { Water gate or } \\
\text { pumping station }\end{array}$} & With water gate or pumping station & 0.018 & 0.027 & 0.027 & 0.027 \\
\hline & Without water gate or pumping station & 0.052 & 0.085 & 0.049 & 0.066 \\
\hline \multirow{3}{*}{ Mobile pumps } & Area with mobile pumps & 0.011 & 0.015 & 0.007 & 0.011 \\
\hline & $\begin{array}{l}\text { No mobile pumps in the area but } \\
\text { within } 3 \mathrm{~km} \text {. }\end{array}$ & 0.023 & 0.031 & 0.014 & 0.023 \\
\hline & Area without mobile pumps & 0.034 & 0.043 & 0.023 & 0.034 \\
\hline \multirow{2}{*}{ Maintenance } & Well maintained & 0.018 & 0.033 & 0.000 & 0.017 \\
\hline & Poorly maintained & 0.092 & 0.102 & 0.007 & 0.064 \\
\hline
\end{tabular}


Table 4 Factor weights of urban inundation due to the failure of broken dikes

\begin{tabular}{|c|c|c|c|c|c|}
\hline Factors & Levels & Govern. & Acad. & Industry & Overall \\
\hline \multirow{4}{*}{ Material of levee } & RC levee & 0.023 & 0.052 & 0.072 & 0.051 \\
\hline & Riprap levee & 0.045 & 0.085 & 0.103 & 0.081 \\
\hline & Earth levee & 0.089 & 0.118 & 0.167 & 0.127 \\
\hline & No levee & 0.139 & 0.150 & 0.199 & 0.166 \\
\hline \multirow{5}{*}{$\begin{array}{l}\text { Material of } \\
\text { revetment }\end{array}$} & $\mathrm{RC}$ revetment & 0.010 & 0.037 & 0.056 & 0.035 \\
\hline & Riprap bank revetment & 0.025 & 0.058 & 0.096 & 0.060 \\
\hline & Cylinder bank revetment & 0.047 & 0.077 & 0.117 & 0.080 \\
\hline & Natural riverbank revetment & 0.047 & 0.089 & 0.143 & 0.093 \\
\hline & No revetment & 0.103 & 0.118 & 0.161 & 0.128 \\
\hline \multirow{3}{*}{ Conditions of levee } & No levee & 0.007 & 0.027 & 0.053 & 0.030 \\
\hline & With $\operatorname{crack}(\mathrm{s})$ & 0.029 & 0.054 & 0.064 & 0.052 \\
\hline & Without crack & 0.078 & 0.103 & 0.141 & 0.112 \\
\hline \multirow{3}{*}{ Position of levee } & Obtuse angle & 0.027 & 0.044 & 0.036 & 0.040 \\
\hline & Parallel & 0.069 & 0.067 & 0.066 & 0.070 \\
\hline & Acute angle & 0.149 & 0.114 & 0.096 & 0.117 \\
\hline \multirow{3}{*}{ Channel slope } & Slight slope & 0.032 & 0.028 & 0.039 & 0.033 \\
\hline & Moderate slope & 0.072 & 0.056 & 0.066 & 0.063 \\
\hline & Steep slope & 0.112 & 0.084 & 0.090 & 0.092 \\
\hline \multirow{4}{*}{ Precipitation } & Under $25 \%$ & 0.017 & 0.049 & 0.028 & 0.036 \\
\hline & Between $25 \%$ to $50 \%$ & 0.050 & 0.065 & 0.043 & 0.055 \\
\hline & Between $50 \%$ to $75 \%$ & 0.093 & 0.097 & 0.067 & 0.088 \\
\hline & Over $75 \%$ & 0.148 & 0.128 & 0.082 & 0.116 \\
\hline \multirow{3}{*}{ Topography } & Out flow & 0.009 & 0.015 & 0.012 & 0.013 \\
\hline & Through flow & 0.025 & 0.026 & 0.025 & 0.026 \\
\hline & In flow & 0.045 & 0.046 & 0.062 & 0.053 \\
\hline \multirow{2}{*}{ Tidal affected river } & $\begin{array}{l}\text { In a tidal affected river } \\
\text { section }\end{array}$ & 0.012 & 0.019 & 0.010 & 0.011 \\
\hline & $\begin{array}{l}\text { Not in a tidal affected river } \\
\text { section }\end{array}$ & 0.034 & 0.023 & 0.021 & 0.025 \\
\hline \multirow{3}{*}{$\begin{array}{l}\text { Stormwater } \\
\text { drainage systems }\end{array}$} & 20 years of FRI flow & 0.013 & 0.028 & 0.023 & 0.023 \\
\hline & 10 years of FRI flow & 0.028 & 0.054 & 0.044 & 0.046 \\
\hline & 5 years of FRI flow & 0.050 & 0.077 & 0.067 & 0.070 \\
\hline \multirow{2}{*}{$\begin{array}{l}\text { Water gate or } \\
\text { pumping station }\end{array}$} & $\begin{array}{l}\text { With water gate or pumping } \\
\text { station }\end{array}$ & 0.016 & 0.040 & 0.013 & 0.018 \\
\hline & $\begin{array}{l}\text { Without water gate or } \\
\text { pumping station }\end{array}$ & 0.049 & 0.049 & 0.036 & 0.045 \\
\hline \multirow{3}{*}{ Mobile pumps } & Area with mobile pumps & 0.010 & 0.014 & 0.009 & 0.012 \\
\hline & $\begin{array}{l}\text { No mobile pumps in the area } \\
\text { but within } 3 \mathrm{~km} \text {. }\end{array}$ & 0.022 & 0.026 & 0.015 & 0.021 \\
\hline & Area without mobile pumps & 0.030 & 0.035 & 0.022 & 0.030 \\
\hline \multirow{2}{*}{ Maintenance } & Well maintained & 0.009 & 0.026 & 0.008 & 0.014 \\
\hline & Poorly maintained & 0.060 & 0.073 & 0.023 & 0.047 \\
\hline
\end{tabular}

AHP was used for analyzing the importance of flood index which is represented by numbers from 0 to 1 . It is important to note that the numbers are not the probabilities of flooding, but comparative indicators of flood risk for the individual $200 \times 200 \mathrm{~m}^{2}$ cells, with larger values indicating higher flood risk. To analyze the potential for inundation due to the failure of stormwater drainage systems or broken dikes, all the factors causing flooding have been analyzed and illustrated by the GIS software (Fig. 9 to 12).

Fig. 9 shows the results of the AHP inundation analysis due to the failure of 
stormwater drainage systems as well as the historical inundated areas for both Taichung City and Fushin Township. The historically inundated areas are based to different flood reports during the typhoon seasons in 2004-2005.

Higher AHP-based potential for inundation, 0.56-0.65, is found mainly in the northern and southern parts of the Fazih River in Taichung City, as well as along some other parts of the river. The average potential for inundation is between 0.51 and 0.55 in Taichung City. The AHP flood map shows an over-estimation at western and northern part of the Fazih River.

The higher AHP-based potential for inundation, 0.56-0.65, is mainly distributed along the river in Fushin Township. The average potential for inundation in Fushin Township is between 0.46 and 0.50 . An over-estimation is shown in the AHP flood map where the downstream section of Fushin River.

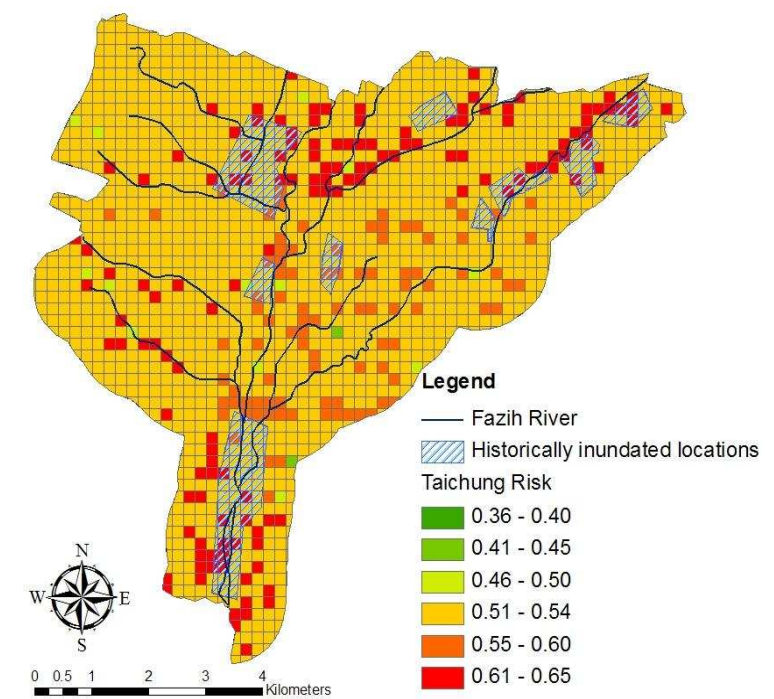

Fig. 9 Potential of inundation due to the failure of drainage systems in Fazih River with 1 kilometer buffer in Taichung City

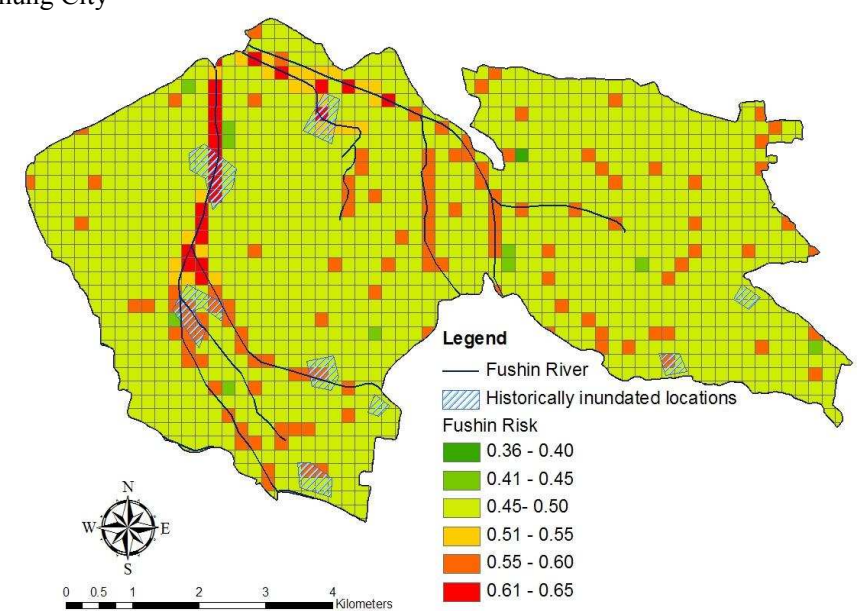

Fig.10 Potential of inundation due to the failure of drainage systems Fushin Township

In order to assess the flood risk caused by broken dikes, 200 meters simulated 
buffers of those two rivers in the study areas were analyzed and the results are shown in 200 by 200 meter cells (Fig. 11 and Fig. 12). After the river overflows the broken dikes into drainage areas, flooding became inundation due to the failure of drainage systems. The average potential for inundation due to broken dikes is between 0.37 and 0.38 in Taichung City, which is higher than that in Fushin Township, between 0.27 and 0.29

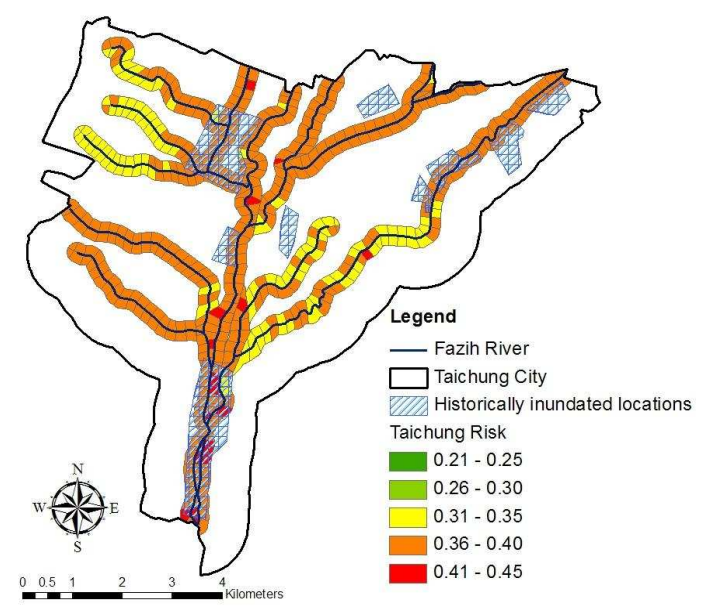

Fig. 11 Potential of inundation caused by broken dikes in the 200 meter buffer of Fazih River in Taichung City

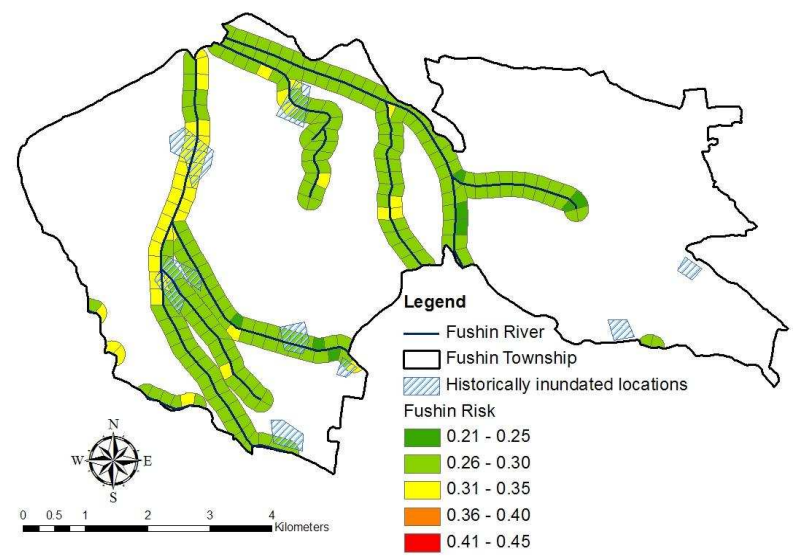

Fig. 12 Potential of inundation caused by broken dikes in the 200 meter buffer of Fushin Rivers

\section{Discussion and conclusion}

In summary, the AHP questionnaire was initially based on the literature review, and feedback from the Taiwanese government and universities, as well as chartered professional engineers. The questionnaire in relation to the flood risk due to failed drainage systems or broken dikes was finalized based on the experts' agreement. The AHP questionnaire was designed to form the basis of the research and included the factors that might cause and prevent floods and reduce flood damage. The questionnaire was then answered by hydraulic and flooding control experts from the related fields. These experts were selected from different areas and regions, thereby 
reducing the bias in their response.

The results of the questionnaire were shown as numerical values to present the potential of inundation. In the study areas, this was evaluated by giving weights to the flood risk for each $200 \times 200 \mathrm{~m}^{2}$ unit. The weights represent comparative measures of the degree of flooding between the units, with larger values indicating higher flood risk.

Traditionally, hydrologic/hydraulic models were commonly used to assess the potential areas of inundation and flood damage for given recurrence intervals. In essence, these models are only based on the balance of the flow and the conveyance of waterways. AHP, as tested for the two areas in Taiwan, provides a more detailed risk index, which combines physiographic indicators with flood mitigation infrastructure, and perceived risk factors by experts working in the field of flood control and floodplain management. The AHP-based approach to flood risk assessment is relatively inexpensive, easy to use, and more importantly, allows interactive use by flood managers for continuing improvement.

However, AHP has its own problems and challenges. Data used for analyzing flood risk were derived from different sources, in different formats, periods and resolutions. Therefore, it was difficult to standardize the dataset for evaluating the flood risk factors for different regions. For example, the data from Taichung City, Fushin Township, and the Water Resources Agency were standardized for this research. Some factors had the same weights in the two study areas. The factor of the stormwater drainage systems had the same weight in each of the $200 \times 200 \mathrm{~m}^{2}$ cells in Taichung City. This does not affect the quality of ranking the flood factors because many other factors were weighted differently. The higher weights highlight the importance of flood factors, which give flood control planner a better understanding of where flood mitigation measures are needed.

When compared to observed inundation areas in 2004 and 2005, the AHP flood maps have over-estimated the risk for a few areas in both Taichung City and Fushin Township. The over-estimation may be an indication of the perceived risk, and the relative importance of flood-causing factors by the experts in the field of flood management. The areas of over-estimation probably indicate the potential flooding sites in the future, where flood prevention works may be needed.

In addition, further improvements of the flood risk assessment using the AHP/GIS method can be achieved by using longer rainfall/flood records, adding more factors and dividing the factors into more risk categories, and by refining the AHP approach through working iteratively with the experts.

In conclusion, comprehensive flood risk analysis often requires detailed information on field conditions, hydrologic statistics, and features of flood-defense structures so that probability-based result can indicate the extent and severity of the impact of flood on the specific areas. With the methodology proposed in this study, the flood potential as measured by the integration of AHP and GIS can provide a preliminary estimation of the flood risk in the catchment or on a regional scale. Furthermore, AHP could provide a more detailed and meaningful assessment of flood risk and an interactive assessment with the decision makers.

AHP-based flood risk assessment would help flood managers and local community leaders to understand the factors causing inundation on the flood plains. For example, the Central Water Resources Agency could use this AHP flood risk assessment to allocate funds and distribute resources to each Taiwanese city for flood control. The AHP rating indices and numerical results can be used by flood managers as a reference for flood control planning and flood defense in Taichung City and Fushin Township. The underlying structure for the questionnaire for flood 
risk assessment is based on the generic characteristics of Taiwan. Therefore the methodology can be readily applied to most other areas in Taiwan where the required data sets are already available for this type of flood risk assessment.

\section{Acknowledgements}

The authors would like to thank the Water Hazard Mitigation Center of Water Resources Agency, Ministry of Economic Affairs of Taiwan for supporting this research work, under Grant No. 94021914, and the reviewers for the constructive comments to improve the quality of the paper.

\section{References}

Anselmo V, Galeati G, Palmieri S, Rossi U, Todini E (1996) Flood risk assessment using an integrated hydrological and hydraulic modelling approach: a case study. J Hydrol 175:533-554. Doi: 10.1016/S0022-1694(96)80023-0

Booij MJ (2005) Impact of climate change on river flooding assessed with different spatioal model resolutions. J Hydrol 303(23):1-4. doi: 10.1016/j.jhydrol.2004.07.013

Boroushaki S, Malczewski J (2010) Using the fuzzy majority approach for GIS-based multicriteria group decision-making. J Comput \& Geosci 36(3):302-312. doi: 10.1016/j.cageo.2009.05.011

Brimicombe AJ, Bartlett JM (1996) Linking geographic information systems with hydraulic simulation modelling for flood risk assessment: the Hong Kong approach. Goodchild MF (ed), GIS and environmental modelling, Oxford University Press, New York

Chen LC, Teng WH, Hsu MH, Lai MJ (2000) Practical aspects on applying the inundation potential map for Taiwan. J Taiwan Water Conservancy 48: 13-19 (in Chinese)

Chen SP, Wang RY (2004) Analyzing hazard potential of typhoon damage by applying grey analytic hierarchy process. Nat hazards 33(1):77-103. doi:10.1023/B:NHAZ.0000035019.39096.b5

Central Weather Bureau (2009) Historical data of typhoon. http://rdc28.cwb.gov.tw/data.php. Least up date: 08 December 2009

Golden BL, Wasil EA, Levy DE (1989) Applications of the analytic hierarchy process: a categorized, annotated bibliography. In The Analytic Hierarchy Process: Applications and Studies, SpingerVerlag, Berlin pp 37-58

Grigg NS, Botham LH, Rice L, Shoemaker WJ, Tucker LS (1975) Urban drainage and flood control projects economic, legal and financial aspects. Colorado State University, Fort Collins

Jonkman SN, Gelder PHAJM, Vrijling JK (2003) An overview of quantitative risk measures for loss of life and economic damage. J Hazard Mater 99(1):1- 30. doi: 10.1016/S0304-3894(02)00283-2

Lin CY, Lin WT, Chou WC (2001) WinGrid basic. Wei-Shuai, Taichung City (in Chinese)

Meyer V, Scheuer S, Haase D (2009) A multicriteria approach for flood risk mapping exemplified at the Mulde river, Germany. Nat hazards 48(2): 17-39. Doi: 10.1007/s11069-008-9244-4

Saaty TL (1980) The analytic hierarchy process. McGraw- Hill, New York

Sinha R, Bapalu GV, Singh LK, Rath B (2008) Flood risk analysis in the Kosi river basin, north Bihar using multi-parametric approach of analytical hierarchy process (AHP). In: reports and documents. Indian J Indian Society of Remote Sensing 36(4):335-349

Smith DI (1994) Flood damage estimation-a review of urban stage-damage curves and loss functions. Water SA 20(3):231-238

Taichung City Council (2006) Report of A Pre-Plan for Production of Local Inundation Lost Maps: Investigation and Analysis of the Inundation Lost, Storms, and Typhoons in 2004 and 2005 by Department of Bioenvironmental Systems Engineering, National Taiwan University (in Chinese)

Wang RY, Huang HY, Cheng SP (2002) The study of fuzzy analytic hierarchy process and grey system theory for analyzing the damage potential of inundation effect. Taiwan Water Conserv 50:1-23 (in Chinese)

Water Resources Agency, Taiwanese Ministry of Economic Affairs (2006) Regulation project of floodprone areas. http://www.ncdr.nat.gov.tw/chinese/DLinu/DLpage.htm. Least up date: 26 December 2006

Willet K, Sharda R (1991) Using the analytic hierarchy process in water resource planning: selection of flood control projects. J Scio-Econ Plann Sci 25(2):103-112

Zadeh LA (1968) Probability measures of fuzzy events. J Math anal and appl (23)2:421-427. doi: 10.1016/0022-247X(68)90078-4

Zhang J, Okada N, Tatano H, Hayakawa S (2002) Risk assessment and zoning of flood damage caused by heavy rainfall in yamaguchi prefecture, Japan. Wu BS (ed), Flood defence, Science Press, Beijing, 
pp 162-169 